\title{
Strategi Internalisasi Nilai Keagamaan pada Siswa Sekolah Menengah Pertama di Masa Covid-19
}

\author{
Muhammad Salman Alfarizi \\ Univesitas Islam Negeri (UIN) Sunan Ampel Surabaya \\ salmanalfarizi6889@gmail.com \\ Farid Arrasid \\ Univesitas Islam Negeri (UIN) Sunan Ampel Surabaya \\ faridarrasid@gmail.com \\ Imam Syafi'i \\ Univesitas Islam Negeri (UIN) Sunan Ampel Surabaya \\ imamsyafii.iwa.@gmail.com
}

\begin{abstract}
Covid-19 was declared as one of the pandemic outbreaks on an international scale, with the existence of covid teaching and learning activities that were originally running in normal social conditions were hampered and transferred to the latest technological advances, using several applications and platforms that support teaching and learning activities. However, some parties consider that this transfer is an ineffective solution, especially in an effort to instill religious values in junior high school (SMP) students. This study uses a literature study research model by utilizing existing literature and contextualized with current situations and conditions. This study presents information in a descriptive qualitative narrative. This study argues that online learning is an ineffective activity. The authors propose a reverse theory and find that there are several solutions in the process of internalizing religious values in junior high school students. This can be overcome with a varied, attractive, and active learning model. In addition, the responsibility and role of the environment has a significant influence in the succession of teaching and learning activities in order to implement the cultivation of good religious values in junior high school students.
\end{abstract}

Keywords: Strategy, Internalization, Religious V alues, Junior High School Students, Covid-19.

Abstrak: Covid-19 dinyatakan sebagai salah satu wabah pandemi skala internsional, dengan adanya covid kegiatan belajar mengajar yang semula berjalan dalam keadaan sosial normal terhambat dan di alih tugaskan pada kemajuan teknologi terkini, dengan menggunakan beberapa aplikasi dan platform yang mendukung KBM tetap berjalan. Namun, beberapa pihak menganggap bahwa pengalihan ini merupakan solusi yang kurang efektif, terlebih dalam upaya penanaman nilai keagamaan pada siswa Sekolah Menengah Pertama (SMP). Studi ini menggunakan model penelitian studi kepustakaan dengan memanfaatkan literatur yang ada dan di kontekstualisasikan dengan situasi dan kondisi terkini, penelitian ini menyajikan informasi dalam narasi yang bersifat deskriptif kualitatif. Penelitian ini membantah bahwa belajar dalam jaringan (daring)

Belajea: Jurnal Pendidikan Islam Vol. 6, No 2, 2021; 107-120

p-ISSN 2548-3390; e-ISSN 2548-3404, DOI: 10.29240/belajea.v6i2.2406

available online at:http://journal.staincurup.ac.id/indek.php/belajea 
merupakan kegiatan yang kurang efektif, penulis mengemukakan teori berbalik dan menemukan bahwa terdapat beberapa solusi dalam proses internalisasi nilai keagamaan pada siswa SMP. Hal ini dapat di tanggulangi dengan model belajar yang variatif, atraktif, dan aktif. Selain itu, tanggungjawab dan peran lingkungan memiliki pengaruh yang cukup signifikan dalam suksesi kegiatan KBM guna terselenggaranya penanaman nilai keagamaan yang baik pada siswa SMP.

Kata Kunci: Strategi; Internalisasi; Nilai Keagamaan; Siswa SMP; Covid-19.

\section{PENDAHULUAN}

Belajar merupakan perintah yang dituturkan langsung oleh baginda nabi Muhammad Saw dalam hadisnya, di dalamnya rasul mewajibkan setiap individu dari umatnya untuk melaksanakan apa yang menjadi substansi dalam hadis rasul, para ulama' hadis kemudian mengafirmasi kewajiban tersebut dan menambahkannya bahwa dalam belajar tidak ada perbedaan dalam objek hukum wajibnya. Selain itu Allah SWT juga secara implisit dalam kitab al-Qur'an Surat al-Qalam ayat 1-5 memerintahkan manusia untuk belajar, baik belajar baca tulis aksara maupun belajar membaca situasi dan keadaaan lingkungan sekitar.

Adapun secara esensial belajar merupakan proses perubahan dalam diri manusia, baik dalam ranah kognitif, afektif maupun psikomotoriknya. Dalam literatur selanjutnya di tekankan bahwa hasil dari proses belajar merupakan perubahan yang bersifat tetap, artinya bahwa perubahan-perubahan yang dialami oleh individu ini bukanlah merupakan sesuatu yang momentum, tetapi lebih condong mengarah kepada hal-hal yang bersifat tetap dan bertahan dalam jangka waktu yang lama.

Unsur perubahan tidak akan lepas dan selalu ditekankan dalam setiap gagasan tentang belajar mengajar, sebagaimana menurut Witherington yang dikutip oleh Nana Syaodih "belajar adalah suatu proses perubahan yang berkaitan dengan kepribadian, yang diimplementasikan dalam bentuk berbagai macam pola respon baru yang berupa sikap, kebiasaan, pengetahuan, kecakapan dan keterampilan. ${ }^{1}$

Selanjutnya konsep belajar yang lurus dan sahih di kemukakan oleh Prof. Ah Zakki Fuad dalam jurnalnya, beliau menggagas sebuah ide taksonomi transenden teosentris berbasis pada al-Quran bahwa hasil akhir dari pendidikan yang paling utama adalah suatu karakter yang mengandung nilai-nilai ketuhanan

1 Nana Syaodih Sukmadinata, Metode Penelitian Pendidikan (Bandung: PT Remaja Rosdakarya, 2011), hlm. 155. 
di dalamnya. ${ }^{2}$ Artinya bahwa walaupun dalam perjalanannya tujuan daripada pendidikan Islam ini mengalami berbagai perubahan dan telah melewati dinamika yang sedemikian banyaknya mulai dari tujuan-tujuan yang simpleks hingga tujuan yang bersifat kompleks, Tetap dapat di tekankan bahwa harus terdapat manusia-manusia atau pun produk dari pendidikan itu sendiri merupakan seseorang yang berisi dalam nilai-nilai keagamaannya. Adapun kemudian dimensi-dimensi yang harus terpenuhi adalah dimensi Ilahiyah (ketuhanan), Insaniyah (kemanusiaan) dan Kawniyah (alam semesta) sebagai indikator pencapaian atau parameter keberhasilan dari terselenggaranya pendidikan di Indonesia.

Kemudian yang menjadi sebuah permasalahan adalah bahwa internalisasi atau pun proses transformasi nilai dalam penanaman karakter pada peserta didik ternyata mengalami berbagai problematika, terlebih dalam situasi dan kondisi yang memaksa setiap institusi pendidikan menyelenggarakan kegiatan belajar mengajar secara dalam ruangan (daring) atau biasa di sebut online kembali menuai banyak problem dan keluhan dalam pelaksanaannya. Dalam situasi yang serba perihatin di era ini menuntut seluruh elemen bangsa dan negara untuk memperhatikan aspek kesehatan karena dampak dari Covid-19 terbukti sangat luas sehingga federasi kesehatan dunia menetapkan covid-19 ini sebagai bencana berskala internasional dan tergolong dalam pandemi.

Penyelenggaraan pendidikan yang sehat tidak menjamin adanya internalisasi nilai keagamaan yang optimal apabila dalam pelaksanaannya tidak terkonsep dengan baik dan serius, apalagi dengan segala keterbatasan yang diakibatkan oleh covid-19 semakin memaksa tenaga pendidik untuk bekerja lebih keras lagi dalam mendidik kader bangsa. Efek yang di rasakan setelahnya merupakan hal yang patut untuk diperhatikan, dimana ketika urgensi karakter ini di kesampingkan maka yang akan muncul ke permukaan esok hari adalah hasil didikan yang prematur karena tidak memenuhi standar kaum intelek. Oleh karenanya perlu di lakukan upaya-upaya lainnya untuk menangani problematika hari ini yakni dalam rangka optimalisasi internalisasi nilai-nilai keagamaan dalam dunia pendidikan Indonesia era covid-19 membutuhkan terobosan dan strategi lainnya agar terselenggara pendidikan yang sehat dan baik bagi satuan pendidikan di Indonesia.

2 Ah. Zakki Fuad, "Rekonstruksi Tujuan Pendidikan Islam Berbasis Taksonomi Transenden", ISLAMICA: Jurnal Studi Keislaman, Vol. 9, No. 2 (Maret 2015), hlm. 425. Dalam https://doi.org/10.15642/islamica.2015.9.2.424-446. 


\section{PEMBAHASAN}

\section{Karakteristik Belajar Siswa Sekolah Menengah Pertama}

Jika dilihat dalam tahapan-tahapan perkembangan manusia, siswa SMP ini berada pada tahap periode perkembangan Operasional formal (umur 11/1218 tahun). Akan tetapi, kebanyakan para ahli setuju bahwa anak yang sudah memasuki jenjang sekolah menengah pertama (SMP) bisa dipastikan sama halnya mereka sedang berada pada posisi tahap perkembangan pubertas (10-14 tahun). Anak sudah bisa berpikir abstrak dan logis, hal tersebut merupakan ciri utama perkembangan pada tahap ini. ${ }^{3}$ Oleh karena itu, pada tahap ini anak sudah mulai memiliki kemampuan dalam menarik kesimpulan, menafsirkan dan mengembangkan hipotesa atau yang lebih dikenal dengan model berpikir ilmiah dengan tipe bipotetico-deductive dan inductive.

Menurut Samiudin dalam artikel yang ditulisnya berpendapat bahwa siswa yang telah menginjak usia SMP berada pada tahap periode perkembangan yang sangat pesat dari segala aspek, terutama aspek yang ada hubungannya dengan pembelajaran, antara lain perkembangan aspek psikomotor, kognitif dan afektif. ${ }^{4}$

Menurut Jean Piaget (1970) dalam penelitiannya, saat anak memasuki usia 12 tahun, dimana pada usia tersebut rata-rata anak telah masuk pada jenjang sekolah menengah pertama (SMP) itu berarti anak tersebut telah memasuki suatu periode yang dikenal dengan "period of formal operation" atau tahap/periode operasional formal. Yakni perkembangan intelektual yang biasa terjadi pada rentang usia 11-15 tahun. Pada tahap ini ada beberapa perubahan kondisi berfikir yang dialami oleh si anak, yaitu: 1) melakukan suatu pekerjaan secara inovatif dan efektif, 2) melakukan analisa secara kombinasi, 3) kemampuan berpikir yang proporsional, dan 4) menggeneralisasikan segala sesuatu secara mendasar pada satu macam isi. ${ }^{5}$

Sehingga pada masa ini, siswa SMP mengalami perkembangan yang berupa kemampuan untuk berpikir simbolik dan pemahamannya mengenai segala sesuatu menjadi lebih bermakna (meaningfully) walau tanpa memerlukan objek yang konkret, bahkan objek yang visual. Sehingga dapat dikatakan bahwa

${ }^{3}$ Meriyati, Memahami Karakteristik. Anak Didik (Lampung: Fakta Press 1AIN Raden Intan Lampung, 2015), hlm. 26.

4 Samiudin, "Pentingnya Memahami Perkembangan Anak Untuk Menyesuaikan Cara Mengajar Yang Diberikan”, PANCAW AHANA: Jurnal Studi Islam, Vol.12, No.1 (April 2017), hlm. 4.

${ }^{5}$ Sugiman, dkk., GURU PEMBELAJAR MODUL MATEMATIKA SMP KELOMPOK KOMPETENSI A PEDAGOGIK KARAKTERISTIK SISWA SMP (TKP: Kementerian Pendidikan Dan Kebudayaan, 2016), hlm. 17. 
siswa SMP sudah tidak kesulitan lagi dalam memahami segala sesuatu yang sifatnya imajinatif.

Perkembangan karakteristik lainnya yang dialami oleh anak usia SMP yaitu; 1) Biasanya antara proporsi tinggi dan berat badan sering terjadi ketidakseimbangan, 2) Mulai timbulnya ciri-ciri seks sekunder, 3) Lebih cenderung mengalami ambivalensi, seperti contoh antara keinginan untuk menyendiri dengan keinginan untuk bergaul dengan teman sebayanya, dan juga keinginan untuk bebas dalam aktivitas dengan kebutuhan bimbingan dan bantuan dari orangtua, 4) menjadi suka membandingkan kaidah-kaidah, nilainilai etika atau norma dengan kenyataan yang terjadi pada kehidupan orang dewasa, 5) Mulai bersifat skeptis dengan mempertanyakan tentang eksistensi dan sifat-sifat Tuhan. 6) Reaksi dan ekspresi emosi masih labil. 7) Muncul keinginan untuk mengembangkan standar dan harapan terhadap perilaku diri sendiri yang sejalan dengan lingkungan sosial sekitarnya 8) mulai tampak kejelasan dalam hal memilih minat dan karier. ${ }^{6}$

\section{Urgensi Nilai Keagamaan pada Siswa Sekolah Menengah Pertama}

Bangsa Indonesia merupakan suatu bangsa yang besar, semua orang mengakui bahwa terdapat banyak sekali ragam perbedaan dalam bangsa ini. Adapun perbedaan-perbedaan tersebut kerap sekali memicu terjadinya sebuah konflik, sebut saja sejak era Gus Dur (Presiden Abdurrahman Wahid) hingga kini konflik dan permasalahan seputar rasisme mulai berkurang, ${ }^{7}$ walaupun dalam beberapa momen masih saja kita temui permasalahan serupa. Untuk inilah nilai keagamaan berperan dalam karakter pemuda bangsa, terlebih pada usia anak sekolah menengah upaya-upaya preventif untuk mencegah terjadinya halhal negatif harus terus di upayakan, terbukti masih kerap kita temui tawuran antar pelajar Sekolah Menengah Atas bukan menjadi hal yang langka, hal ini tentu saja berhubungan dengan pendidikan pada masa sebelumnya yakni masa Sekolah Menengah Pertama. Oleh karena itu lah di perlukan adanya internalisasi nilai keagamaan yang baik dalam kerangka pendidikan nasional.

Pendidikan berasal dari kata Yunani Pedagogie yang ditransliterasikan ke dalam bahasa Indonesia menjadi 'Pendidikan', secara etimologi Pedagogie terdiri dari dua kata Pais yang artinya anak, dan again yang artinya bimbing dalam bahasa Yunani, dari sini dapat disimpulkan secara bahasa pendidikan merupakan bimbingan yang diberikan kepada anak. ${ }^{8}$ Adapun secara terminologi pendidikan

\footnotetext{
${ }^{6}$ Desmita, Psikologi Perkembangan (Bandung: PT. Remaja Rosdakarya, 2010), hlm. 36.

7 Eko Handoyo Tijan, Model Pendidikan Karakter berbasis Konservasi (Semarang: Widya Karya Press, 2010), hlm. 1.

${ }^{8}$ Mardianto, Psikologi Pendidikan: Landasan untuk Pengembangan Strategi Pembelajaran (Medan: Perdana Publishing, 2016), hlm. 2.
} 
didefinisikan oleh Teguh Triwiyanto bahwa pendidikan merupakan usaha menarik sesuatu yang tersimpan di dalam diri manusia sebagai upaya mencetak realita empirik belajar terprogram dalam bentuk pendidikan formal, non formal, dan informal di sekolah maupun di luar sekolah, yang berlangsung selama seumur hidup dan bertujuan untuk mengoptimalisasi potensi individu tersebut agar dapat memainkan peranan hidup secara tepat sasaran di kemudian hari. ${ }^{9}$ Singkatnya, pendidikan merupakan usaha sekelompok orang untuk mencapai kedewasaan dan merangkak menuju kesempurnaan mental yang lebih tinggi.

Pendidikan yang baik adalah pendidikan yang menekankan pada nilainilai luhur bangsa, agama dan negara, nilai merupakan bahasan vital yang perlu sedikit dikupas dalam hal ini agar tercipta pemahaman yang lurus dalam koridor ini. Kata 'nilai' dalam bahasa lnggris ialah "value", sedangkan dalam bahasa latin yaitu "velere", atau dalam bahasa Prancis kuno "valoir", yang memiliki arti memiliki kegunaan, kemampuan akan, berdaya, berlaku, bermanfaat dan memiliki kebenaran yang pasti menurut keyakinan seseorang atau kesepakatan sekelompok orang". 10 Dalam kamus besar bahasa Indonesia kata 'nilai' mempunyai arti sebagai sifat-sifat (hal-hal) yang penting atau berguna bagi kemanusiaan, atau sesuatu yang menyempurnakan manusia sesuai dengan hakikatnya. ${ }^{11}$ Berangkat dari pemaparan di atas dapat digaris bawahi bahwa nilai merupakan idealisme dari pada sebuah proses pendidikan, sehingga secara substantif pendidikan diselenggarakan untuk menanamkan nilai-nilai luhur yang masih berlaku dan berkembang di masyarakat.

Sedangkan agama secara definitif adalah seperangkat ajaran yang terdiri dari perangkat nilai-nilai kehidupan yang harus dijadikan tolak ukur para penganutnya ketika menentukan pilihan ketika bertindak dalam kehidupannya. Nilai-nilai ini secara populer disebut dengan nilai agama. ${ }^{12}$ Dalam kamus besar bahasa Indonesia kata 'agama' memiliki makna ajaran atau sistem yang mengatur tata keimanan (kepercayaan) dan peribadatan kepada Tuhan Yang Maha Kuasa serta tata kaidah yang berhubungan dengan pergaulan manusia dan manusia serta lingkungannya. ${ }^{3}$ Dalam kamus ilmiah, religius (keagamaan) diartikan sebagai “taat kepada agama”. ${ }^{14}$ Istilah 'keagamaan' itu sendiri awalnya berasal

${ }_{9}$ Teguh Triyanto, Pengantar Pendidikan (Jakarta: PT Bumi Aksara, 2014), hlm. 23-24.

10 Sutarjo Adisusilo, JR., Pembelajaran Nilai Karakter (Jakarta: PT Rajagrafindo Persada, 2012), hlm. 56.

11 Kamus Besar Bahasa Indonesia (online), dalam https://kbbi.web.id/nilai. Diakses pada (22 Januari 2021).

${ }^{12}$ Muhammad Alim, Pendidikan Agama Islam (Bandung: Remaja Rosdakarya, 2011), hlm. 10.

${ }^{13}$ Kamus Besar Bahasa Indonesia (online), dalam https://kbbi.web.id/agama. Diakses pada (22 Januari 2021).

${ }^{14}$ Happy El Rais, Kamus Ilmiah Populer (Yogyakarta: Pustaka Pelajar, 2012), hlm. 536. 
dari istilah 'agama'. Walaupun memiliki akar kata yang sama, akan tetapi dalam penggunaannya kedua kata tersebut yaitu agama dan keagamaan tentu memiliki perbedaan makna. Istilah agama (religi) lebih tertuju pada aspek formal yang berkaitan dengan aturan-aturan dan kewajiban-kewajiban, sedangkan istilah keagamaan (religius) lebih tertuju pada aspek agama (religi) yang telah terinternalisasi di dalam kepribadian suatu individu.

Pentingnya penanaman nilai-nilai keagamaan pada peserta didik ialah agar mereka menjadi manusia yang berakhlak, beretika serta berbudaya sebagai bagian dari tujuan pendidikan nasional, serta memfungsikan nilai-nilai keagamaan sebagai patokan atau standar kebenaran dan kebaikan. Kemudian hal penting yang perlu kita ketahui bersama bahwa nilai-nilai agama merupakan nilai luhur atau nilai kebajikan yang telah mengalir dan telah diadopsi ke dalam diri manusia. Sehingga baik dan buruknya perilaku manusia tersebut sangat tergantung dan erat kaitannya dengan kualitas dan kuantitas nilai-nilai agama yang merasuk/terinternalisasi di dalam dirinya. Semakin baik kualitas nilai-nilai agama yang terinternalisasi dalam diri seseorang, maka kepribadian dan sikap religiusnya akan tampak dengan sendirinya dan terbentuk menjadi suatu karakter. Dan jika sikap religius/keagamaan sudah tampak dan terbentuk menjadi suatu karakter, maka nilai- nilai agama akan menjadi pusat nilai atau pedoman yang paling utama dalam menyikapi segala sesuatu dalam kehidupan.

Seiring dengan proses perjalanannya menjadi sebuah bangsa yang maju, unggul dan bermartabat, konflik sosial, tawuran antar pelajar dan merosotnya nilai-nilai nasionalisme serta nilai kebangsaaan dan wersternisasi (proses masuknya budaya barat ke Indonesia) membuat nilai-nilai kearifan lokal Indonesia menjadi terabaikan. Dengan sebuah konsep yang tertata rapi mengenai pendidikan karakter, maka diharapkan peserta didik yang menimba ilmu pada jenjang tersebut memiliki kualitas lebih baik daripada generasi sebelumnya. Itulah sebabnya, mereka perlu dibekali dengan pendidikan karakter dengan tujuan agar potensi intelektual yang mereka miliki dapat di imbangi dengan nilai-nilai yang berhubungan dengan kecerdasan emosional, sosial dan spiritual agar dapat berkompetisi dalam kancah internasional.

Dalam dunia kependidikan mengenali potensi manusia sebagai individu merupakan suatu hal penting, ${ }^{15}$ dimana pengenalan tersebut bertujuan untuk memahami secara utuh kepribadian seseorang, hal ini tentu di lakukan dengan cita-cita memberdayakan manusia dengan mengenali potensi diri yang ada pada manusia itu sendiri. Pengendalian lingkungan menjadi salah satu kunci dalam membangun kepribadian yang baik, oleh karenanya sekolah maupun lingkungan pendidikan wajib menyeleggarakan pendidikan yang sehat dan bersih. Adapun

${ }^{15}$ Mardianto, Psikologi Pendidikan., hlm. 227. 
dengan hal ini maka menjadi suatu tanggung jawab tersendiri begi institusi pendidikan di Indonesia untuk mengacu pada kurikulum yang telah di tetapkan oleh kementrian pendidikan dan kebudayaan yang ada, dan di era ini, kerangka pendidikan nasional lebih diarahkan kepada hal-hal yang bersifat aplikatif untuk pemberdayaan manusia unggul yang berkarakter kedepannya. Oleh karena itu, pembelajaran pendidikan agama yang dilaksanakan di sekolah yang merupakan bentuk upaya penanaman nilai-nilai keagamaan dapat diinternalisasikan melalui kegiatan intra maupun ekstra sekolah serta tetap lebih mengutamakan pengamalan ajaran agama dalam kehidupan sehari-hari. ${ }^{16}$

\section{Kondisi Pembelajaran di Masa Pandemi Covid-19}

Sesulit apa pun keadaannya, setiap anak berhak atas pendidikan. Sepenggal kalimat ini sangat pantas untuk ditujukan pada situasi dan kondisi terkini di era pandemi covid-19, Pendidikan merupakan hak asasi manusia, setiap individu berhak untuk mendapatkan pendidikan yang layak dan memadai, entah dengan cara bagaimana pun jua apa yang menjadi hak-hak warga negara harus terlaksana dalam rangka menciptakan penerus bangsa yang maju dan bedikari sesuai dengan pembukaan UUD 1945 alinea ke-4 tentang salah satu tujuan dari beridirinya Indonesia adalah dalam rangka mencerdaskan kehidupan bangsa.

Walaupun dalam suasana duka nan memprihatinkan, pembelajaran pada saat ini tetap berjalan apa adanya, dengan segala keterbatasan fasilitas, tempat, waktu ditambah dengan aturan protokol kesehatan yanmg sebegitu ketatnya mengakibatkan penyelenggaraan pendidikan saat ini kurang optimal. ${ }^{17}$ Ternyata, situasi kondisi kesehatan dan perekonomian yang tidak sehat berimbas pula pada kesehatan pendidikan bangsa ini.

Namun, di sisi lain ketika banyak orang menganggap bahwa pandemi merupakan sebuah alasan bagi kegagalan cita-cita pendidikan dan kemundurankemunduran yang terjadi, terdapat beberapa hal positif yang dapat di amati dalam penyelenggaraan pendidikan satu tahun terkahir. Peran teknologi dalam pendidikan agaknya kian menarik, dengan beralih nya model pembelajaran saat ini menjadi sutau model pembelajaran online (dalam jaringan) membuka peluangpeluang baru dalam mencipta kreatifitas yang segar. Tidak dapat di pungkiri

${ }^{16}$ Nur Ainiyah, "Pembentukan Karakter Melalui Pendidikan Agama Islam", Jurnal AlUlum (Jurnal Studi-Studi Islam) LAIN Gorontalo, Vol. 13 No.1, (Juni 2013), hlm. 30.

${ }_{17}$ Muhammad Ashari, "Proses Pembejalaran Daring di Tengah Antisipasi Penyebaran Virus Corona Dinilai Belum Maksimal”, PikiranRakyat.com dalam https://www.pikiranrakyat.com/pendidikan/pr-01353818/proses-pembejalaran-daring-di-tengah-antisipasipenyebaran-virus-corona-dinilai-belum-maksimal di akses pada 24 Januari 2021. 
bahwa keberhasilan pembelajaran kini tergantung pada efektifitas dan efisiensi penggunaan teknologi dalam penerapannya.

Kondisi telah menuntut setiap institusi untuk mengoptimalkan teknologi dalam proses belajar mengajar, telepon pintar (smartphone) merupakan salah satu media yang saat ini banyak digunakan untuk mendukung kegiatan belajar mengajar, ${ }^{18}$ adapun beberapa variasi dalam model pembelajaran online terbagi menjadi beberapa metode, bahkan hingga kini tercatat puluhan aplikasi dan fasilitas yang berbasis internet dan teknologi yang tercipta, hal ini dapat dibuktikan dengan maraknya aplikasi-aplilkasi baru yang dapat di install dalam smartphone dan beberpaa platform yang berguna bagi pembelajaran seperti: Google Classromm. Google Meet, Zoom, Schoology, Ilmupedia, Ruang Guru, Zenius, dan lain sebagainya. Bahkan, di beberapa perguruan tinggi mulai menggunakan media sosial untuk di alih fungsikan menjadi media belajar pula. Adapun media sosial yang popular di gunakan sebagai media pembelajaran adalah Youtube dan Instagram. Dengan berbagai terobosan baru di bidang pendidikan dan teknologi tentunya tenaga pendidik kini seharusnya tidak mempermasalahkan dimana dan kapan harus belajar, sejatinya belajar itu dapat dilakukan kapan pun dan dimana pun seseorang berada.

Namun pada kenyataannya dibalik segala kemajuan yang tercapai di bidang teknologi dan pendidikan memunculkan suatu persoalan baru. Apakah teknologi mampu menggantikan peran guru dalam proses internalisasi nilai? Tentunya hal ini menjadi pertanyaan besar, mengingat di awal pendahuluan telah kita bahas cita-cita pendidikan negara Indonesia.

Setelah di amati dengan baik, ternyata pergeseran budaya pendidikan yang seperti ini kurang efektif dalam internalisasi nilai pada anak, terbukti bahwa dengan peran teknologi yang semakin mendominasi pendidikan ttidak berjalan sesuai dengan apa yang di harapkan. Dengan tidak bertatap muka secara langsung membuat peserta didik jenuh dan pada akhirnya menyebabkan mereka kurang memperhatikan intisari materi yang di jelaskan oleh guru. Terlebih dalam model pembelajaran yang saat ini berjalan berpotensi besar meraih kegagalan dalam mencipta karakter dan lurus dan baik bagi peserta didik. Selain itu, masa remaja pada tingkat anak sekolah menengah pertama cenderung memiliki emosi yang labil sehingga penggunaan smartphone harus di awasi secara kontinu oleh orang tua agar tidak di gunakan pada hal-hal yang tidak semestinya seperti

\footnotetext{
${ }^{18}$ Dian Ihsan, 'Ini 'Curhat' Guru, Siswa, Mahasiswa, dan Orangtua Soal Pembelajaran Daring", Kompas.com dalam https://www.kompas.com/edu/read/2020/09/15/095539371/ini-curhat-guru-siswamahasiswa-dan-orangtua-soal-pembelajaran-daring?page=all di akses pada 24 Januari 2021.
} 
membuka situs-situs pornografi dan membuka game berlebihan yang tidak pada tempatnya.

Kekhawatiran seperti ini dapat di atasi dengan pemilihan tata cara serta strategi yang tepat dalam penerapan model pembelajaran daring, dalam rangka meminimalisir potensi-potensi kegagalan yang ada maka strategi jitu mengenai internalisasi dan upaya-upaya lainnya untuk mengoptimalisasikan usaha-usaha yang di lakukan dalam proses belajar mengajar perlu adanya keseriusan dari beberapa pihak terlebih lingkungan sekitar yang mendukung adaptasi pola belajar siswa sekolah menengah pertama.

\section{Strategi Internalisasi Nilai Keagamaan pada Anak SMP di Masa Pandemi Covid-19}

Dalam hal pelaksanaan strategi internalisasi keagamaan, seorang pendidik diharapkan terus berperan aktif dan kreatif disertai sikap semangat dan pantang menyerah agar tujuan dari strategi yang telah direncanakan dapat diterima oleh peserta didik dan terealisasikan dalam kehidupan sehari-hari. Tidak hanya itu, sikap semangat dan pantang menyerah yang selalu ditampakkan oleh guru secara tidak langsung hal tersebut akan menjadi teladan bagi peserta didik. Sebaliknya, apabila seorang guru tersebut terlihat tidak yakin dengan kemampuannya atau kurang semangat, maka para siswa pun akan merasa raguragu dengan gurunya sendiri bahkan mungkin saja bisa menjadi acuh terhadap intruksi dari gurunya.

Menurut Abdul Majid dalam bukunya, mengartikan strategi sebagai suatu pola yang telah direncanakan dan ditetapkan secara sengaja dan terstruktur untuk menyelenggarakan suatu kegiatan atau tindakan. Dalam strategi ini telah mencakup tujuan kegiatan, siapa yang terlibat dalam kegiatan, isi kegiatan, proses kegiatan dan sarana penunjang kegiatan. ${ }^{19}$

Apalagi kita semua sekarang tengah dihadapkan dalam situasi yang serba sulit dan ribet, para guru tidak bisa bertatap muka dengan muridnya sehingga tak dapat menyampaikan materinya dengan leluasa dan juga para murid tidak bisa berkomunikasi secara langsung dengan gurunya sehingga tak dapat memahami materi dengan seutuhnya.

Untuk menghadapai problem yang demikian, para lembaga pendidikan bersama seluruh tenaga pendidiknya harus mencarikan jalan alternatif demi tetap terselenggaranya pembelajaran dan para anak-anak yang bersekolah tetap mendapat haknya sebagai murid yaitu mendapatkan materi dari gurunya lebihlebih mereka mampu untuk memahami dan mengamalkannya.

${ }^{19}$ Abdul Majid, Strategi Pembelajaran (Bandung: PT Remaja Rosdakarya, 2013), hlm. 3. 
Seperti halnya saat ingin melaksanakan proses internalisasi nilai-nilai keagamaan kepada peserta didik, tentunya kita butuh persiapan yang matang mulai dari rencana, strategi, materi dan lain sebagainya. Apalagi yang menjadi obyeknya adalah anak-anak usia SMP yang dimana pada masa-masa ini karakter kekanak-kanakan di waktu SD cenderung masih nampak, inilah yang perlu dipahami oleh para guru SMP.

Internalisasi itu sendiri dapat diartikan sebagai usaha menghayati dan mendalami nilai supaya nilai tersebut tertanam dalam diri setiap manusia. ${ }^{20}$ Oleh karena itu, dalam melaksanakan internalisasi nilai-nilai keagamaan pada anakanak usia SMP dapat dilakukan dalam beberapa tahapan antara lain;

1. Tahapan penyampaian materi: dalam tahapan ini seorang guru menjelaskan dengan serinci mungkin tentang materi keagamaan yang sedang dipelajari dan sesuai dengan kurikulum yang ada. Seorang guru semaksimal mungkin dapat meyakinkan murid-muridnya ketika menyampaikan informasi tentang nilai-nilai yang baik dan nilai-nilai yang tidak baik. Dengan kata lain, seorang guru harus dapat memposisikan dirinya sebagai motivator bagi muridmuridnya.

2. Tahapan tanya jawab: dalam tahapan ini seorang guru semaksimal mungkin dapat memberikan solusi atau jalan keluar atas apa saja nantinya yang menjadi persoalan murid-muridnya. Setelah materi dipaparkan oleh guru tentu akan timbul pertanyaan-pertanyaan dari murid-murid. Tetapi terkadang mereka takut untuk menyampaikan segala sesuatu yang mengganjal di benaknya. Untuk itu, sebisa mungkin seorang guru bersikap akrab dan ramah kepada peserta didiknya agar peserta didik tidak merasa sungkan atau bahkan takut untuk menyampaikan segala sesuatunya kepada gurunya sendiri. Dengan kata lain, pada tahapan ini seorang guru sebisa mungkin memposisikan dirinya sebagai konsultan bagi murid-muridnya.

3. Tahapan pengamalan: dalam tahapan ini seorang guru membangkitkan semangat peserta didiknya untuk mengamalkan ajaran nilai-nilai yang didapat dari pembahasan sebelumnya. Dalam praktiknya mungkin seorang guru bisa memberikan tugas yang berisi kegiatan yang harus dilakukan peserta didik untuk menunjang tercapainya internalisasi nilai-nilai keagamaan pada peserta didik. Dengan kata lain, pada tahapan ini seorang guru sebisa mungkin memposisikan dirinya sebagai instruktur yang baik bagi murid-muridnya.

4. Evaluasi: pada tahapan ini seorang guru mungkin dapat mengisinya dengan pemberian apresiasi kepada peserta didik yang mampu melaksanakan tugas-

${ }^{20}$ Muhammad Nurdin, Pendidikan Anti Korupsi; Strategi Internalisasi Nilai-nilai Islami dalam Menumbubkan Kesadaran Antikorupsi di Sekolab (Yogyakarta: Ar-Ruzz Media, 2014), hlm. 124. 
tugas yang diberikan gurunya dan memberikan dukungan moral dari hati ke hati kepada peserta didik yang belum mampu melaksanakan tugas-tugasnya.

Lebih dari itu, tanggung jawab pendidikan tidak hanya terpusat pada instansi, suatu beban moral ini haruslah dipikul oleh berbagai elemen dalam masyarakat. Pendidikan di era ini seharusnya sudah mulai menggeser paradigma baru bahwa peran pemuda sangat penting dalam transformasi keilmuan, jika mahasiswa identik dengan aksi turun jalan dan sebagainya, menyuarakan aspirasi rakyat dan diskusi di sudut-sudut gedung megah kampus, kini saatnya peran mahasiswa dimainkan.

Di beberapa desa peran ini sudah mulai dijalankan oleh sebagian besar pemuda dan pemudi di sekitar, hal ini terbilang efektif mengingat beberapa siswa tidak terpaut jauh besar kemungkinan antara pemuda setempat dan peserta didik memiliki karakter yang cenderung sama, oleh karenanya proses internalisasi nilai keagamaan pada peserta didik cenderung mudah dilaksanakan. Dalam hal ini bisa diadakan kegiatan kursus keterampilan khusus yang banyak diminati oleh siswa usia skeolah menengah pertama seperti futsal, sepakbola, banjari dan sebagainya. Jika siswa dirasa telah menaruh hati pada objek keterampilan tertentu maka kemudian di sana lah peran pemuda selanjutnya dimainkan. Proses penanaman nilai bisa dilakukan dengan cara menasehati ringan, melempar sejumlah candaan ringan, atau pun praktek-praktek tertentu yang memiliki keterkaitan dengan tujuan di adakannya sbeuah kegiatan tersebut.

Di sisi lain, peran pemuda juga tampak dalam beberapa event yang diadakan oleh kalangan pelajar atas dan organisai-organisasi kemahasiswaan tertentu seperti organisasi daerah, Ikatan Pelajar/Pelajar Putri Nahdlatul Ulama' (IPNU-IPPNU), Karang Taruna dan lain sebagainya yang menyelenggarakan kegiatan bertemakan educare (peduli pendidikan). Pada kegiatan semacam ini pemuda menggantikan peran guru dalam menyampaikan materi dan nilai-nilai tertentu, beberapa orang juga membantu tugas-tugas yang di berikan oleh guru di sekolah masing-masing, hal ini tentu sangat membantu siswa dan berpotensi mencipta ikatan emosional di antara volunteer dan siswa, jika tercipta ikatan emosional maka akan lebih mudah bagi volunteer utnuk memasukkan nilai religi kepada siswa tertentu.

Jadi, proses internalisasi nilai-nilai keagamaan pada peserta didik dapat dilakukan oleh semua kalangan, tidak hanya dari seorang guru. Walaupun kondisi pembelajaran yang terjadi pada masa-masa ini dirasa serba sulit, namun hal tersebut bukanlah menjadi hambatan dalam proses internalisasi nilai-nilai keagamaan pada peserta didik. 


\section{KESIMPULAN}

Wabah pandemi covid-19 sangat memberikan dampak yang signifikan di setiap aspek kehidupan, mulai dari ekonomi, sosial, pendidikan dan lain-lain. Kondisi pendidikan di masa pandemi ini memang sangatlah menyulitkan, tidak hanya bagi guru tetapi seluruh anak-anak yang masih bersekolah juga merasakan kesulitannya begitu pun para wali murid yang tak jarang merasa kesulitan dalam mendampingi anaknya saat waktunya belajar sekaligus mengoperasikan gadget sebagai alternatif pembelajaran di masa pandemi ini. Tak berhenti sampai disitu, pembelajaran yang serba daring ini ternyata tidak akan pernah bisa menggantikan keefektifan pembelajaran tatap muka.

Walaupun dalam kondisi seperti ini, penanaman nilai-nilai keagamaan pada peserta didik tetap menjadi hal terpenting untuk dilaksanakan. Terutama bagi anak-anak yang duduk di jenjang SMP, dimana anak-anak pada masa ini lebih rentan terpengaruh oleh dunia luar yang berdampak negatif. Untuk itu, nilai-nilai keagamaan yang sudah terinternalisasi pada setiap peserta didik diharapkan dapat menjadi tameng yang kokoh dari berbagai macam pengaruh negatif.

Melihat problematika yang demikian, seorang guru harus memutar otak berinovasi dengan menyusun strategi pembelajaran yang efektif dan efisien walaupun kondisi pembelajaran tak seperti dulu ketika tatap muka. Keberhasilan strategi internalisasi nilai-nilai keagamaan pada siswa SMP di masa pandemi covid-19 ini sangatlah perlu didukung oleh semua kalangan tidak hanya guru, akan tetapi para orang tua siswa dan masyarakat di lingkungan tempat tinggalnya juga turut berpengaruh.

\section{BIBLIOGRAFI}

Ainiyah, Nur. "Pembentukan Karakter Melalui Pendidikan Agama Islam”, Jurnal Al-Ulum (Jurnal Studi-Studi Islam) IAIN Gorontalo, Vol. 13, No. 1, Juni 2013.

Alim, Muhammad. Pendidikan Agama Islam. Bandung: Remaja Rosdakarya, 2011.

Ashari, Muhammad. "Proses Pembejalaran Daring di Tengah Antisipasi Penyebaran Virus Corona Dinilai Belum Maksimal", PikiranRakyat.com dalam https://www.pikiran-rakyat.com/pendidikan/pr-01353818/prosespembejalaran-daring-di-tengah-antisipasi-penyebaran-virus-corona-dinilaibelum-maksimal.

Desmita, Psikologi Perkembangan. Bandung: PT. Remaja Rosdakarya, 2010. 
Fuad, Ah. Zakki. "Rekonstruksi Tujuan Pendidikan Islam Berbasis Taksonomi Transenden", ISLAMICA: Jurnal Studi Keislaman, Vol. 9, No. 2, Maret 2015. Dalam https://doi.org/10.15642/islamica.2015.9.2.424-446.

Ihsan, Dian. "Ini 'Curhat' Guru, Siswa, Mahasiswa, dan Orangtua Soal Pembelajaran Daring", Kompas.com dalam https://www.kompas.com/edu/read/2020/09/15/ 095539371/inicurhat-guru-siswa-mahasiswa-dan-orangtua-soal-pembelajarandaring?page $=$ all.

JR, Sutarjo Adisusilo. Pembelajaran Nilai Karakter. Jakarta: PT Rajagrafindo Persada, 2012.

Kamus Besar Bahasa Indonesia (online), dalam https://kbbi.web.id.

Majid, Abdul. Strategi Pembelajaran. Bandung: PT Remaja Rosdakarya, 2013.

Mardianto. Psikologi Pendidikan: Landasan untuk Pengembangan Strategi Pembelajaran. Medan: Perdana Publishing, 2016.

Meriyati, Memahami Karakteristik. Anak Didik. Lampung: Fakta Press IAIN Raden lntan Lampung.

Nurdin, Muhammad. Pendidikan Anti Korupsi; Strategi Internalisasi Nilai-nilai Islami dalam Menumbubkan Kesadaran Antikorupsi di Sekolah. Yogyakarta: Ar-Ruzz Media, 2014.

Rais, Happy El. Kamus Ilmiah Populer. Yogyakarta: Pustaka Pelajar, 2012.

Samiudin, "Pentingnya Memahami Perkembangan Anak Untuk Menyesuaikan Cara Mengajar Yang Diberikan", PANCAW AHANA: Jurnal Studi Islam, Vol.12, No.1, April 2017.

Sugiman, dkk., GURU PEMBELAJAR MODUL MATEMATIKA SMP KELOMPOK KOMPETENSI A PEDAGOGIK KARAKTERISTIK SISW A SMP. TKP: Kementerian Pendidikan Dan Kebudayaan, 2016).

Sukmadinata, Nana Syaodih. Metode Penelitian Pendidikan. Bandung: PT Remaja Rosdakarya, 2011.

Tijan, Eko Handoyo. Model Pendidikan Karakter berbasis Konservasi. Semarang: Widya Karya Press, 2010.

Triyanto, Teguh. Pengantar Pendidikan. Jakarta: PT Bumi Aksara, 2014. 